\title{
Enzymatic Hydrolysis of Liquid Hot Water Pre-treated Macro- alga (Ulva lactuca) for Fermentable Sugar Production
}

\author{
Tri Poespowati ${ }^{1, *}$, Ardy Riyanto ${ }^{1}$, Hazlan $^{1}$, Ali Mahmudi ${ }^{2}$, and Rini Kartika-Dewi ${ }^{1}$ \\ ${ }^{1}$ Department of Chemical Engineering, National Institute of Technology, J1. Bend. Sigura-gura 2, Malang, Indonesia \\ ${ }^{2}$ Department of Electrical Engineering, National Institute of Technology, Jl. Bend. Sigura-gura 2, Malang, Indonesia
}

\begin{abstract}
Ulva lactuca is one of green macro-algae that has a significant cellulose content. This study aims to determine the effect of variations in substrate-enzyme ratio and hydrolysis time on the enzymatic hydrolysis process of cellulose extracted from Ulva lactuca to produce fermentable sugar or reducing sugar as a raw material for making bioethanol. Firstly, Liquid Hot Water (LHW) pre-treatment process was performed at the temperature of $135^{\circ} \mathrm{C}$ for 20 minutes; the purpose of this pre-treatment was to reduce the content of hemicellulose and to increase the cellulose content. Secondly, enzymatic hydrolysis process using cellulase enzyme was carried out, in this process citrate buffer was needed in order to stabilize the $\mathrm{pH}$ level during hydrolysis process. The process variables were ratio of substrate-enzyme $(1: 0.05 ; 1: 0.1$; $1: 1.5 ; 1: 2$ and $1: 2.5 \mathrm{w} / \mathrm{w})$ and hydrolysis time (24, 48 and 72 hours) under temperature of $45^{\circ} \mathrm{C}$ and $\mathrm{pH}$ level of 5.5. The results shows that the highest reducing sugar yield is $79.7 \%$ obtained at a ratio of substrate-enzyme of 1:2.5 (w/w) for 48 hours of hydrolysis time, with the result of reducing sugar concentration is $16.2043 \mathrm{mg} / \mathrm{mL}$.
\end{abstract}

Corresponding author: poespowati@lecturer.itn.ac.id 


\section{Introduction}

The world energy demand continues to increase. This increase occurred from the requirement of 90 million barrels per day in 2012 to 100 million barrels in 2020, and raise in volume of 121 million barrels in 2014 [1]. Therefore, in order to fulfil the fuel consumption, alternative renewable energy from biomass sources is necessary; one of them is by converting biomass into bioethanol.

Ethanol is a renewable fuel that can be obtained from fermentation process of mono-sugar. To replace a part of gasoline comes from fossil sources; ethanol fuel has already applied in the US as gasoline fuel additive [2]. This can help to reduce the problem in the decline of fossil fuel reserves and its use as a fuel and chemical raw materials [3]. There are 3 generation types of bioethanol: first generation bioethanol produced from molasses or by-product of refining sugarcane, second generation bioethanol made from lignocellulosic agricultural waste and third generation bioethanol obtained from cellulosic biomass such as algae.

Some researches claim that ethanol made from cellulosic materials is a significant fuel in the future if its technology faces the important improvement [4]. One of the cellulosic natural resources that can be converted into bioethanol is green macro alga Ulva lactuca, this alga widely available in nature especially along the coast of the South Island of Java, Indonesia [5]. To obtain monosugar for fermentation purposes, polysaccharides in cellulose content of biomass material can be broken down by chemical hydrolysis or enzymatic hydrolysis [6]. Enzymatic hydrolysis process in order to convert cellulose biomass into bioethanol involves three basic steps: first step is pre-treatment process, second step is hydrolysis process, and the third step is fermentation process. By pre-treatment process, lignin content and hemicellulose content in biomass can be removed or decreased, and long chain sugar contained in cellulose can be broken easily into mono sugar. This is due to the increasingly porous of biomass [2].

Liquid Hot Water (LHW) is one of the most pretreatment procedures to break down hemicellulose from lignocellulosic materials. LHW pre-treatment process can be carried out in temperature range of $120{ }^{\circ} \mathrm{C}$ and $200{ }^{\circ} \mathrm{C}$ [7] or $120{ }^{\circ} \mathrm{C}$ and $260{ }^{\circ} \mathrm{C}$ [8], and can be conducted in a simple way by using an autoclave in a ratio of solid sample/water by $1 / 5(\mathrm{w} / \mathrm{v})$ [9]. LHW pretreatment process has several advantages: the process is environmentally friendly because it does not require any chemicals other than water $[8,10]$, high sugar yields can be obtained; and compared to the pre-treatment process using acid hydrolysis, the LHW pre-treatment process effect provides minimal corrosion in the equipment caused by mild $\mathrm{pH}$ levels of the reaction [10]. This pretreatment is used to enhance the ability of enzymes to degrade cellulose by dissolving hemicellulose, reduce the degradation of sugar products, minimize the formation of HMF (5-hydroxymethyl furfural) and furfural that can be inhibit enzymatic hydrolysis process and yeast fermentation process [11].
Enzymatic hydrolysis of cellulose can be carried out by cellulase enzyme [11]. Reducing sugar and glucose are the products of this enzymatic hydrolysis $[2,11]$ in relatively high percentage (75\%-95\%) compared with the usage of acid hydrolysis [12]. Bacteria and fungi can produce cellulase enzymes for hydrolysis of lignocellulosic materials, which trichoderma is the most microbes for cellulase enzyme production [2]. Cellulase is part of hidrolases group containing endo-glucanase, exo-glucanase and beta-glucosidase [11, 13]. Endoglucanase act on cellulose derivatives by cutting at random and cause breakdown of long chain into the short chain rapidly. Furthermore, exo-glucanase splitting glucose continuously from non-reduced ends of the chain glucan-free and produce cellobiose (disaccharide of glucose). Then beta-glucosidase degrades cellobiose into glucose [14].

The purpose of this research is to investigate the effect of substrate-enzyme ratio and hydrolysis time to enzymatic hydrolysis process of LHW pre-treated green macro-alga (Ulva lactuca) to produce high reducing sugar content as a raw material of bioethanol alternative fuel.

\section{Experimental Method}

\subsection{Materials}

Green macro-alga Ulva lactuca was collected from Kukup beach, Yogyakarta, Indonesia. Chemicals supplied by PT Panadia Malang and CV Makmur Sejati Malang - Indonesia. The chemicals used in this study were fehling A, fehling B, ethanol 98\% (Merck), sulphuric acid 98\% (Merck), sodium citrate (Merck), citric acid (Merck), dinitrosalisilic acid (Sigma), phenol (Merck), sodium hydroxide (Merck) and sodium sulphite (Merck). All of chemical used was in pure condition, without any further purification process. Cellulase enzyme was supplied by Biotechnology Laboratory, Sidoarjo - Indonesia.

\subsection{Sample Preparation}

Ulva lactuca was carefully cleaned from sand and other impurities with tap water and then rinsed by distilled water, followed by sun drying then oven drying at $50^{\circ} \mathrm{C}$ until stable weight was reached [5]. To increase the surface area of mass transfer, dry Ulva lactuca was pulverized by using a blender into about 80 meshes in particle size. Content analysis of hot water soluble (HWS), hemicellulose, cellulose, lignin and ash (HHCLA) was conducted on sample prior pre-treatment procedure.

Lignin content and ash content of Ulva lactuca result in extremely small concentration and they can be ignored, the most component dominated in this alga were HWS (51\%), hemicellulose $(27.67 \%)$ and cellulose $(20.33 \%)$. Both of these hemicellulose and cellulose concentration were relevant with the concentration stated by Saini where the concentration of hemicellulose and

\footnotetext{
Corresponding author: poespowati@lecturer.itn.ac.id
} 
cellulose of green algae are in the range of (20-50\%) and $(20-40 \%)$ respectively [14].

\subsection{Pre-treatment process of Liquid Hot Water (LHW)}

During Liquid Hot Water pre-treatment process, 10 gr of dried Ulva lactuca was added to $100 \mathrm{ml}$ of distilled water $(10 \% \mathrm{w} / \mathrm{v})$. The mixture was then heated in an autoclave at temperature of $135^{\circ} \mathrm{C}$ for 20 minutes. After LHW pre-treatment process, Chesson method analysis [15] is needed to be conducted in order to determine the amount of dissolved hemicellulose and other component that might be change such as cellulose, HWS and lignin.

\subsection{Enzymatic Hydrolysis}

The pre-treatment process explained above was followed by enzymatic hydrolysis process. For this purpose, $100 \mathrm{~mL}$ of pre-treatment product was added by $67 \mathrm{~mL}$ of buffer citrate (ratio 1:0.67 v/v). Before addition of cellulase enzyme was actuated, $\mathrm{pH}$ level of mixture must be maintained at about 5.5 by using sodium citrate or citric acid. Furthermore, cellulase enzyme was added with ratio substrate-enzyme of $1: 0.05,1: 0.1,1: 1.5,1: 2$ and 1:2.5 $\mathrm{w} / \mathrm{w}$; and it was shaken in a water-bath shaker at temperature of $45^{\circ} \mathrm{C}$ and hydrolysis time of 24, 48 and 72 hours. Hydrolysate was separated from its solid. In turn liquid hidrolysate was analysed on reducing sugar qualitatively using Fehling solution and quantitatively using DNS method [16].

\section{Results and Discussion}

\subsection{Pre-treatment Process}

The purpose of pre-treatment process was to increased cellulose content and to reduced hemicellulose content of Ulfa lactuca, in turn; cellulase enzymes convert cellulose into reducing sugar easily. Initial analysis of reducing sugar content on Ulva lactuca resulted in $3.489 \mathrm{mg} / \mathrm{mL}$.

Cellulose in material structure is covered by hemicellulose and lignin. Hemicellulose in raw material acts as a barrier for the enzymes to degrade cellulose [17-19]. It causes cellulase enzyme hard to reach cellulose and obstruct the way of cellulose become reducing sugar. Lignin also tightly covers cellulose fibres and inhibits enzyme to degrade cellulose [19]. That is why pre-treatment process has to be done in order to dissolve the hemicellulose content. Table 1 provides a summary of the component weight in percentage of Ulva lactuca before and after pretreatment process. And Figure 1 shows a typical history of HHC: Hot water soluble (HWS), hemicellulose, and cellulose content before and after pre-treatment processes.
Table 1. Result of liquid hot water pre-treatment.

\begin{tabular}{|l|c|c|}
\hline \multicolumn{1}{|c|}{ Component } & $\begin{array}{c}\text { Before pre- } \\
\text { treatment (\% w) }\end{array}$ & $\begin{array}{c}\text { After pre- } \\
\text { treatment (\% w) }\end{array}$ \\
\hline $\begin{array}{l}\text { Hot Water } \\
\text { Soluble (HWS) }\end{array}$ & 51 & 47.4 \\
\hline Hemicellulose & 27.67 & 17.8 \\
\hline Cellulose & 20.33 & 33.5 \\
\hline Lignin & 1.3 & - \\
\hline
\end{tabular}

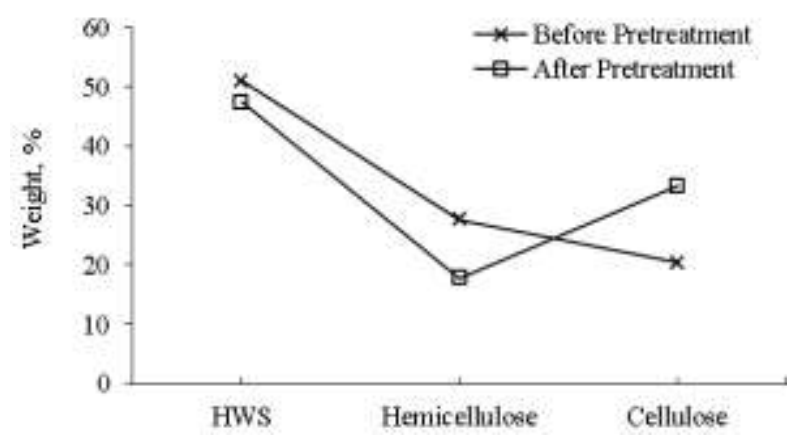

Fig. 1. HHC profile of Ulva lactuca before and after pretreatment process.

It can be seen from Table 1 and Figure 1, after the actuation of pre-treatment process, the weight percentages of both HWS and hemicellulose were decreased from $51 \%$ to $47.4 \%$ and from $27.67 \%$ to $17.8 \%$ by weight respectively, on the other hand the weight percentage of cellulose was increased from $20.33 \%$ to $33.5 \%$ by weight. Lignin content on Ulva lactuca was quite small $(1.3 \% \mathrm{w})$, and it can be predicted that lignin was solubilized in total. The less weight of lignin can be ignored, this has in general matching with those reported by Saini [14]. It can be concluded that the pre-treatment temperature of $135{ }^{\circ} \mathrm{C}$ able to decrease the weight of HWS and hemicellulose and also able to increase the weight of cellulose in a significant number.

Agreeing with Tutt's experiment, the increasing weight of cellulose after pre-treatment process confirms that the binder of cellulose can be broken down successfully [20]. This is simply because when Ulva lactuca was exposed to the high enough of temperature, the cell structure will be broken.

\subsection{Hydrolysis Process}

Cellulase enzyme activities were examined prior to enzymatic hydrolysis work. The examination of cellulase enzyme activities was conducted twice by using DNS method [16], result in 2.3199 Unit/gram and 2.3128 Unit/gram.

Those two parameters of enzyme activities are much smaller than the parameter that was found by Kumar and 
Wyman [21]. The amount of enzyme activity of their experiment was 7.5 Unit/gram, which was done with substrate/enzyme ratio of 1:0.02 (w/w), and producing $90 \%$ of sugar yield [21]. In this research, in order to increase the yield of sugar with the low enzyme activity, the ratio of substrate/enzyme should be increased at the range of 1:0.05 and 1:0.25 (w/w). And all results of qualitative analysis of sugar content in solution resulted in brick-red precipitate as a presence of glucose in the solution.

Coding system of hydrolysis work is provided in Table 2.

Table 2. Encoding variables.

\begin{tabular}{|c|c|c|c|c|c|}
\hline $\begin{array}{c}\text { Coded } \\
\text { level }\end{array}$ & $\mathbf{- 2}$ & $\mathbf{- 1}$ & $\mathbf{0}$ & $\mathbf{+ 1}$ & $\mathbf{+ 2}$ \\
\hline $\begin{array}{l}\text { Ratio of } \\
\text { substrate/en } \\
\text { zyme (w/w) }\end{array}$ & $1: 0.05$ & $1: 0.1$ & $1: 0.15$ & $1: 0.2$ & $1: 0.25$ \\
\hline $\begin{array}{l}\text { Hydrolysis } \\
\text { time hours) }\end{array}$ & & 24 & 48 & 72 & \\
\hline
\end{tabular}

Table 3 shows the influences of substrate/enzyme ratio $(\mathrm{w} / \mathrm{w})$ and hydrolysis time on reducing sugar concentration and yield of sugar. The volume of applied hydrolysate was $100 \mathrm{ml}$ for every single analysis.

As Table 3 quantified, the highest concentration of reducing sugar $(19.6933 \mathrm{mg} / \mathrm{mL})$ was resulted from the ratio of substrate/cellulase enzyme by 1:0.25 (w/w) corresponds to 48 hours of hydrolysis time. On the other hand, the lowest concentration of reducing sugar (4.76 $\mathrm{mg} / \mathrm{mL}$ ) was obtained from the ratio of substrate/cellulase enzyme by 1:0.05 (w/w) corresponds to 72 hours of hydrolysis time. It means that due to obtain the high concentration of reducing sugar; the role of substrate/cellulase enzyme ratio was more significant than hydrolysis time. Table 3 can be visualized as in Figure 2.

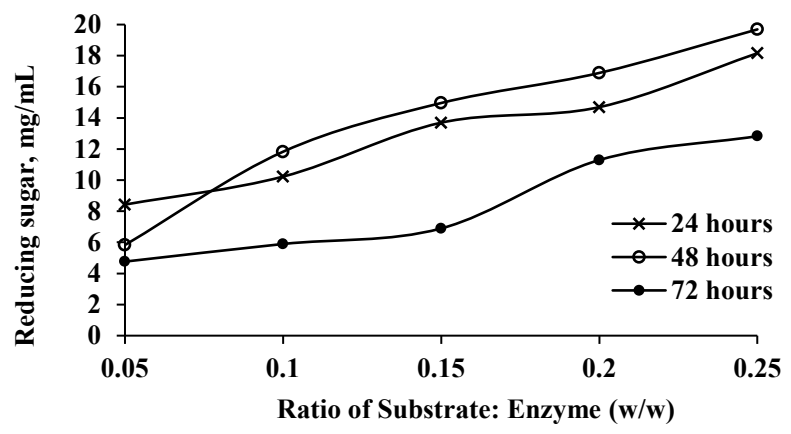

Fig. 2. Reducing sugar concentration versus substrate/enzyme ratio $(\mathrm{w} / \mathrm{w})$ corresponds to hydrolysis time

As shown in Figure 2, for all of hydrolysis times, shows that the concentration of reducing sugar increases as the increase of substrate/enzyme ratio. In general, for all ratio of substrate/enzyme, the highest concentration of reducing sugar produced by 48 hours of hydrolysis time, followed by 24 hours oh hydrolysis time, and the less one was obtained by the application of hydrolysis time by 72 hours. Only one point looks unlike that phenomena, which is at ratio of substrate/enzyme of 1:0.05 $(\mathrm{w} / \mathrm{w})$ where the reducing sugar concentration increases by the decrease of hydrolysis time. Compared with the two results of reducing sugar concentration by the addition of 1:0.05 $(\mathrm{w} / \mathrm{w})$, concentration of reducing sugar resulted by 48 hours of hydrolysis time should be higher than the application of 24 hours of hydrolysis time. This exception result might be caused by the $\mathrm{pH}$ level of this point is higher than the others (see Table 3). It means that high $\mathrm{pH}$ level affects to the decrease of reducing sugar concentration.

Table 3. Independent variables of substrate/enzyme ratio and hydrolysis time employed of reducing sugar concentration and yield of sugar.

\begin{tabular}{|c|c|c|c|c|}
\hline $\begin{array}{c}\text { Ratio of } \\
\text { substrate/ } \\
\text { enzyme }(w / w)\end{array}$ & \begin{tabular}{|c|}
$\begin{array}{c}\text { Hydrolysis } \\
\text { time } \\
\text { (hours) }\end{array}$ \\
\end{tabular} & $\begin{array}{l}\text { Hydrolisate } \\
\text { pH level }\end{array}$ & $\begin{array}{c}\text { Reducing } \\
\text { sugar } \\
(\mathrm{mg} / \mathrm{ml})\end{array}$ & $\begin{array}{c}\text { Yield } \\
(\%)\end{array}$ \\
\hline-2 & -1 & 5.4 & 8.4267 & 24.3 \\
\hline-1 & -1 & 5.3 & 10.2267 & 33.1 \\
\hline 0 & -1 & 5.4 & 13.6933 & 50.2 \\
\hline+1 & -1 & 5.4 & 14.6933 & 55.1 \\
\hline+2 & -1 & 5.4 & 18.1600 & 72.2 \\
\hline-2 & 0 & 5.9 & 5.8267 & 11.5 \\
\hline-1 & 0 & 5.3 & 11.8267 & 41.0 \\
\hline 0 & 0 & 5.3 & 14.9600 & 56.4 \\
\hline+1 & 0 & 5.4 & 16.8933 & 65.9 \\
\hline+2 & 0 & 5.3 & 19.6933 & 79.7 \\
\hline-2 & +1 & 5.3 & 4.7600 & 6.3 \\
\hline-1 & +1 & 5.4 & 5.8933 & 11.8 \\
\hline 0 & +1 & 5.4 & 6.8933 & 16.7 \\
\hline+1 & +1 & 5.4 & 11.2933 & 38.4 \\
\hline+2 & +1 & 5.4 & 12.8267 & 45.9 \\
\hline
\end{tabular}

The experiment result as figured out in Figure 2 can be pictured out by a different graph as shown in Figure 3 that shows the relationship between concentrations of 
reducing sugar and hydrolysis time with different ratio of substrate/enzyme.

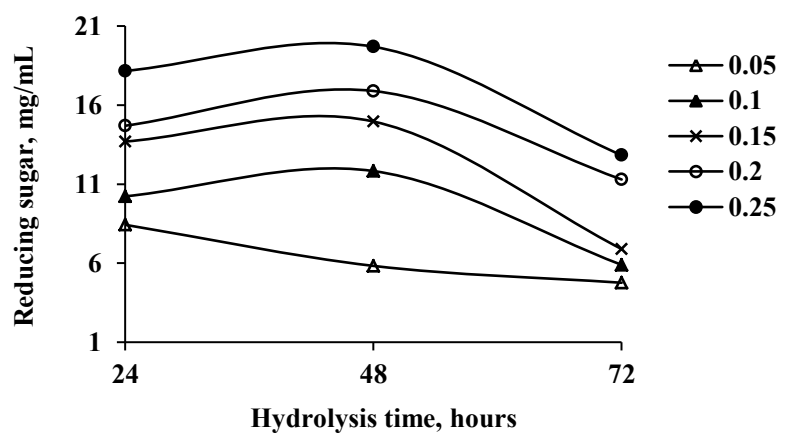

Fig. 3. Reducing sugar versus hydrolysis time corresponds to substrate/enzyme ratio $(\mathrm{w} / \mathrm{w})$.

As illustrated in Figure 3, the highest reducing sugar concentration is obtained under 1:0.25 (w/w) ratio of substrate/enzyme corresponds to all hydrolysis times. This concentration is getting smaller in sequences for other 4 ratios of substrate/enzyme (1:0.2 w/w, 1:0.15 $\mathrm{w} / \mathrm{w}, 1: 0.1 \mathrm{w} / \mathrm{w}$, and 1:0.05 w/w respectively). In all curves, the lowest number of reducing sugar is at 72 hours of hydrolysis time. This phenomenon is understood as the consequence of enzyme that became inactive at the critical hydrolysis time. In this case, enzyme turned to be self-inhibitor of hydrolysis process. This occurrence was in agreement with Guerard et.al [22]. Except sugar, cellobiose is a by-product of hydrolysis process that can be an inhibitor during the process [23]. As Xu et.al claim that the reducing sugar and the rate of hydrolysis goes down at extending hydrolysis time after optimum hydrolysis time is obtained [24].

The response of substrate/enzyme ratio and hydrolysis time on the yield of reducing sugar is given in Figure 4.

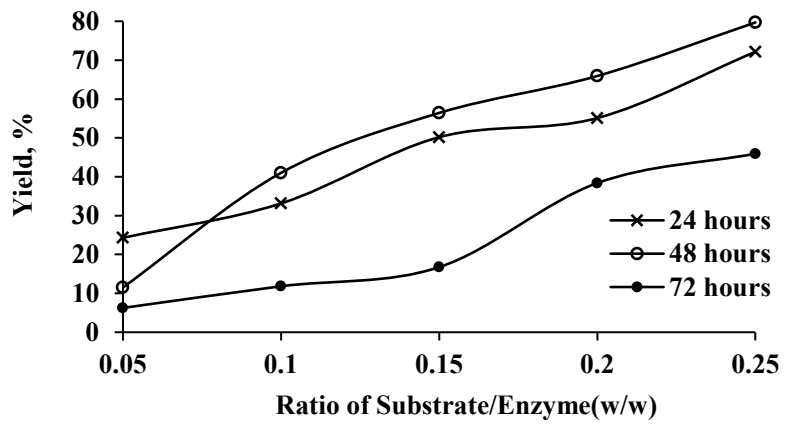

Fig. 4. Reducing sugar yield versus ratio of substrate/enzyme corresponds to hydrolysis times.

The response of substrate/enzyme ratio and hydrolysis time on the reducing sugar yield shown in Figure 4 exposes the high ratio of substrate/enzyme and the modest hydrolysis time tend to enhance yield of reducing sugar (79.7\%). The increase of substrate/enzyme ratio from $1: 0.05 \mathrm{w} / \mathrm{w}$ to $1: 0.25 \mathrm{w} / \mathrm{w}$ under 48 hours of hydrolysis time improves the yield of reducing sugar production from about $11.5 \%$ to $79.7 \%$. The trends of 3 curves in Figure 4 are quite similar to the trends shown in Figure 2.

This work was supported by Ministry of Research, Technology and Higher Education of the Republic of Indonesia for the scheme of Hibah Kompetensi No. 0299/E3/2016, 27 Januari 2016 with an agreement letter of research from "Institut Teknologi Nasional Malang”.

No. ITN.04.189.06/I.LPPM/2016, 25 April 2016.

\section{References}

1. U.S. Energy Information Administration, International Energy Outlook 2016, (2016)

2. Y. Sun, J. Cheng, Bioresource Technology, 83, 1$11(2002)$

3. V. Venkatramanan, S. Aravinth, P.C. Santhosh, M. Nithya, B.K. Sathya, Int. J. of ChemTech Res., 6, 4061-4069 (2014)

4. M. Wang, C. Saricks, D. Santini, 1999, Centre for Transportation Research, Energy Systems Division, (Argonne Nat. Lab., 9700 South Cass Avenue, Illinois, 1999)

5. T. Poespowati, A. Mahmudi, R.K. Dewi, Int. J. of ChemTech Res., 8, 512-518 (2015)

6. J. Payamara, A. Payamara, Int. J. of ChemTech Res., 3, 1446-1449 (2011)

7. Y. Kim, N.S. Mosier, M.R. Ladisch, Biotechnol. Prog. 25, 340-348 (2009)

8. C. Wan, Y. Li, J. Biortech, 102, 9788-9893 (2011)

9. C. Cara, M. Moya, I. Ballesteros, M.J. Negro, A. Gonzalez, E. Ruiz, J. Procbio., 42, 1003-1009 (2007)

10. B. Bharathiraja, T. Sudharsanaa, A. Bharghavi, G.S. Sowmeya, G. Balaram, Int. J. of ChemTech Res., 6, 4434-4444 (2014)

11. R. Dhabhai, A. Jain, S.P. Chaurasia, Int. J. of ChemTech Res., 4, 1497-1502 (2012)

12. Jimmy, T. Poespowati, S. Noertjahjono, Int. J. of ChemTech Res., 8, 188-193 (2015)

13. A.K. Pandey, G. Edgard, S. Negi, J. Renene, xxx, 1-6 (2016)

14. J. K. Saini, L. Tewari.,, R. Saini, 3 Biotech, 5, 337353 (2015)

15. A. Chesson, J. Appl. Bacteriology, 45, 219-230 (1978)

16. G.L. Miller, Analytical Chemistry, 31, 426-428 (1959)

17. Y.Y. Lee, P. Iyer, R.W. Torget, Dilute-Acid Hydrolysis of Lignecellulosic Biomass, J. Biotechnology, 65, 93-115 (1999)

18. M.J. Taherzadeh, K. Karimi, BioResources, 2, 707738 (2007)

19. B. Yang, Z. Dai, S.Y. Ding, C.E. Wyman, Biofuels, 2, 421-450 (2011) 
20. M. Tutt, T. Kikas, H. Kahr, M. Pointner, P. Kuttner, J. Olt, Agronomy Research, 12, 417-424 (2014)

21. R. Kumar, C.E. Wyman, Bioresource Technol., 100, 4203-4213 (2009)

22. F. Guerard, L. Guimas, A. Binet, J. Molecular Catalysis B: Enzymatic, 19-20, 489-498 (2002)

23. T.M. Wood, Biochemical Society Transactions, 13, 407-410 (1985)

24. Z. Xu, Q. Wang, Z.H. Jiang, X. Yang, Y. Ji, Biomass \& Bioenergy, 31, 162-167 (2007) 